\author{
Ebele Angela Udeoji', Ikenna Arthur Amanchukwu²
}

DOI: https://doi.org/10.15804/rop2021210

\title{
MADAGASCAR AND ITS COVID ORGANICS. ISSUES ARISING
}

Key words: covid-19, covid organics syrup, sustainable development

\begin{abstract}
The unrelenting spread of the Corona Virus (Covid-19) pandemic through all nations of the world has sent medical researchers on a frenzied search for a cure. The island nation of Madagascar, in Africa, surprisingly contributed to this global research effort through its 'Covid Organics syrup. Presently, though, the Covid Organics syrup is no longer seriously touted as a viable cure for Covid-19. However, its advancement has thrown up issues relating not only to research and development in itself and in herbal remedies, but also on the ability of herbal development to play a role in ensuring sustainable development. The paper reviews these issues and the potentialities of herbal therapy vis-à-vis the global quest for sustainable development.
\end{abstract}

\section{INTRODUCTION}

Despite the widespread consternation in the global scientific community over Madagascar's herbal mixture for the treatment of the corona virus ailment, the Madagascan president has been unrelenting in the defence of the so called 'formula to save the world' - Covid Organics syrup. On the contrary, empirical outcomes from across Madagascar belie the claims of President Andry Rajoelina of Madagascar. Indeed, as at the time of writing (July 2020), the impotency of Madagascar's Covid Organics has been all

\footnotetext{
1 National Open University of Nigeria (NOUN), Jabi Abuja, ebeleudeoji@yahoo.com.

2 Renaissance University Ugbawka Enugu state Nigeria.
} 
but firmly established. In fact, in spite of its Covid Organics syrup so called the infection rate of the corona virus in Madagascar is in the present danger of spiralling out of control. The frightening spectre of an uncontrollable herd community transmission of the virus has already necessitated the compulsory restriction of movement in certain parts of that country by state authorities (Forku 2020, July 22; "Madagascar hospitals 'overwhelmed"').

Nevertheless, in spite of this 'scientific failure', the Madagascans can claim some victory, though it is at best a pyrrhic victory. Thus amid the scientific ignominy of having its landscape increasingly inundated by the virus in spite of its vaunted syrup, it can be argued that the development of the Covid Organics syrup is in fact a signification of the height reached by Madagascar in scientific research and development. Even more importantly, it depicts a research and development programme which is led, at least in the area of drug research, and in an era of ecologism and environmentalism, by the philosophy of sustainable development. This brief article reviews the development of the Covid Organics syrup by Madagascar and the lessons derivable thereof with regards to research and development vis-à-vis sustainable development.

\section{CORONA VIRUS DISEASE: AN EXPEDITIONARY FORAY}

It is difficult now to tell precisely, given the rapid metastasis of the politics surrounding the corona virus, when the epidemic actually broke out in China. In the first place the Chinese government has often been blamed especially by its main rival, the United States, for repressing news about the spread of the corona virus (Joshi 2020, June 9).

of particular note, it has been suggested that the Chinese central government may have issued viral response guidelines 13 days before the public were informed. This may have delayed the implementation of containment strategies that could have dampened viral spread such as reporting suspected cases in public and the workplace (Sohrabi etal, 2020, p.6). 
Expectedly, China has denied any complicity in the concealment of the spread of the virus from the international community and accused the US of bad faith. It was in response to the abject politicisation and crass misinformation surrounding the pandemic that the World Health Organisation Director-General, Tedros Ghebreyesus, openly declared that: 'we are not just fighting an epidemic; we are infighting an infodemic' (Editorial, 2020, p. 537).

Nonetheless in spite of China's apparent obscurantism and obfuscation and American relentless propaganda (the United States president has not only persisted in referring to the corona virus as the 'China virus' he insists that the virus emanated from a government lab in Wuhan), it is still possible to hazard a guess as to the likely period of the outset of the corona virus pandemic. Already sources hint that in December 2019 an epidemic of unknown aetiology but which bore close similarities to pneumonia had begun to make its appearance felt in Wuhan (Cunningham, Goh \& Koh, 2020 , p. 1). Other sources indicate the virus first broke out in January 2020 (Lau etal, 2020, p. 3). Thus an informed estimate would place the incubation and spread of the virus between November 2019 and early January 2020. However, it is clear that by 7 January, 2020 the virus had been isolated in the Laboratory of Virology Chinese Centre for Disease Control and Prevention (Wang, Cheng, Yue \& Mc Aleer, 2020, p.1). It is also almost uniformly agreed that the virus originated in Wuhan city situated in Hubei province. Wuhan is comprised of an urban area spanning $1528 \mathrm{~km}$ and exceeds 11 million residents.

Further investigations have narrowed the origin of the virus to 'Wuhan's Huanan seafood wholesale market, which trades in fish and a variety of live animal species including poultry, bats, marmots and snakes' (Sohrabi etal, 2020, p. 1). That market has now been closed. It is also beyond doubt that by mid to late January 2019 the virus was already claiming its first victims in China and possibly Italy, with victims displaying symptoms such as dry cough, dyspnea and fever.

The exponential spike in illnesses and death rates forced the WHO to declare the corona virus a Public Health Emergency of International Concern (PHEIC) on January 30, 2020 (Editorial, 2020, p.537). On February 11,2020 WHO announced an official name for the novel Corona Virus 
Disease 2019 as (Covid-19) (Editorial, 2020, p. 537). It is also known as SARS-COV-2, named in honour of its predecessor, SARS-COV-1, which had appeared in Asia in 2002, and belongs to the Beta-coronavirus cluster (Sun etal, 2020, p. 4). On February 18, 2020 WHO reported that there were ' 804 total confirmed cases and three deaths in 25 countries outside China' (Editorial, 2020, p. 537). However other independent sources suggest a more likely higher global figure of 73,451 cases with 1875 deaths as of 19, February 2020 (Wang, Cheng, Yue \& McAleer, 2020, p. 1). In China itself the astounding figure of 68,500 patients as of February 15, 2020 forced the Chinese authorities to completely lockdown the city of Wuhan (Wang, Cheng, Yue \& McAleer, 2020, p. 1), while simultaneously embarking on the expeditious construction of two ultra-modern hospital complexes within two weeks in Wuhan (Sohrabi etal, 2020, p. 5).

The source of Covid-19 virus is equally shrouded in mystery. Several sources have been advanced such as rodents, bats, fish e.t.c. (Sun etal, 2020, p. 5). However, even amidst this pathogenetic nebular a few facts can readily be teased out - that Covid-19 is lethal, especially toward the infirm and elderly. Further studies on the virus indicate that individuals with diabetes mellitus, hypertension and severe obesity are more likely to be infected and are at a higher risk for complications and death from Covid-19' (Muniyappa \& Gubbi, 2020). Equally disturbing is Covid-19's Case Fatality Risk (CFR) among young adults and older adults with comorbidities (Kobayashi, 2020, p. 5). The CFR simply refers to the usual epidemiological practice to assess the severity of a disease obtained by 'simply dividing the number of deaths from a disease by the number of cases of a disease as a function of time' (Kobayashi, 2020, p. 5).

Apart from the fact that Covid-19 is a highly infectious disease which attacks the respiratory system so little else is known about the novel virus that medical sciences appears quite befuddled or simply muddles along. There is at the time of writing no known cure for sufferers of the ailment. At best what obtains generally is that the 'management of patients mainly focuses on the provision of supportive care e.g., oxygenation, ventilation and fluid management' (Cunningham, Goh \& Koh, 2020, p. 1). In the area of medication, the combination of low dose systematic corticosteroids and anti-virals and atomisation inhalation of interferon have been noted as 
being effective in critical Covid-19 management (Cunningham, Goh \& Koh, 2020, p. 1). It is instructive to note here that very early in the 'career' of Covid-19 the Chinese government integrated traditional Chinese medicine with the Western mode toward the treatment of the ailment (Sohrabi, 2020, p. 4). However, in the absence of a vaccine or a reliable regimen of anti-viral drugs, most governments around the world have swerved toward protective and preventive interventions. The one, which targets the individual, aims at 'improving personal hygiene, wearing medical masks, adequate rest and keeping rooms well ventilated' (Sun etal, 2020 , p. 10). The other served as the main bastion of official China's resistance against Covid-19 in the early days of the pandemic. In this regard the Chinese government had decreed measures, now generally adopted worldwide, based on 'classical epidemiology; identify and isolate cases, monitor those contracted, and establish restrictions, including quarantine, on mobility, avoiding events which congregate crowds of people' (Trilla, 2020, p. 2; Parmet and Sinha, 2020, p. 1). However, these procedures are largely holding operations, 'to help 'buy time' for science to catch up before Covid-19 becomes too widespread' (Wu \& McGoogan, 2020, p. 3).

Now 'holding operations' such as the aforementioned are unavoidable in view of the economic consequences of a pandemic especially in China. For example, China's gross domestic production alone is $17 \%$ of the global total and its 'position as the world's largest manufacturer and importer of crude oil has caused economists to nudge down their forecasts for fullyear global growth' (Sohrabi etal, 2020, p. 6). Consequently, in this light, it was expected that an urgent and massive global effort be initiated to halt the rapid spread of the virus (Sohrabi et al, 2020, p. 1). In the main, the vanguard of the worldwide struggle against Covid-19 was held by universities, large pharmaceutical companies, research laboratories and institutions, most of which are engaged in a somewhat symbiotic exchange of ideas. However, while 'there is cooperation on many levels - including among companies that are fierce competitors - hanging over the effort is the shadow of a nationalistic approach that could give the winner the chance to favour its own population and potentially gain the upper hand in dealing with the economic and geostrategic fallout from the crisis' (Sanger et al, 2020, March 19). It was apparent that even 'in the first months 
of the pandemic signs of geopolitical rivalry have been there for all to see and trust lacking even among allies' (Champion, 2020, May 8).

Since 2020 several vaccines have been discovered however given the nationalistic zeal with which the search for a vaccine was pursued, it is only right for one to worry about the impact on the environment. As David Fidler a specialist in cyber security and global health in Council on Foreign Relations observed: 'when it's tense like it is now between the U.S and China, every single thing gets distorted by the geopolitics' (Champion, 2020, May 8). Might a distortion of the global environment not be one of the outcomes of this intense geopolitical 'struggle'?

To be sure, the late 'vaccine race' among the great powers eerily mimics earlier competitive epochs in the international system - one refers to the industrial revolution and the Cold War to be precise - in which unrestrained nationalist impulses led to tragic outcomes for the environment. The early industrial revolution which denuded the vegetative cover of Europe had a significant tincture of European rivalry. In fact, 'due to past patterns of over-reliance on artificial fertilizers and soil tillage, over half of the humus in most temperate-climate soils is gone' (Heinberg, 2006, p.118). The environmental cataclysms of the industrial era formed a somewhat negative continuity with the onset of the Cold War with respect to the demand on the environment. The tragedy for the environment during the Cold War era, as it is presently under 'vaccine nationalism', was the secrecy surrounding most of the research and development of that era. These include the testing of nuclear bombs in the atmosphere, the militarisation of space, the generation and irresponsible disposal of nuclear wastes and so on. The most prominent of the ecological disasters witnessed during the Cold War was the Chernobyl nuclear disaster in 1986 in former Soviet Union which only became known to the outside world because of the extent of damage. It is important to note that the whole schema of environmental protection though operative during the Cold War only acquired additional salience and urgency upon its demise.

Presently, in almost the same way, in the pursuit of the covid-19 vaccine, which can best be qualified as diplomacy by other means, the entire research and development process in the major countries at the forefront of the research had metamorphosed into covert operations. For example, 
both America and China had drafted the military fully into their research process and in Europe there was wild talk of desperation by Russian spy agencies to steal research linked to Covid-19. The U.S accused China and Russia of sponsoring hackers to target labs developing Covid-19 vaccines ("Chinese consulate in Houston ordered to close", 2020, 23 July). In a further escalation of the matter the US charged two Chinese men for intellectual theft ("US charges Chinese Covid-19 research cyber-spies", 2020, 21 July). However, as a western official confessed, 'understanding vaccine research and other details about the pandemic has become a top target for intelligence agencies around the world and many others, including western spies, are likely to be active in this space' (Fox \& Kelion, 2020, July 16).

It is therefore from this perspective that there is the foreboding that the 'nationalisation' of the search for a corona virus vaccine, which has assumed the hue of the Cold War era with its arms race, would reverberate in one form or another upon the environment. Already in the fevered race to be the first to discover a vaccine most countries had jettisoned basic procedures associated with drug research and development. As Charles Andrianjara, director in Madagascar's Malagasy Institute of Applied Research [IMRA], pungently observed in his acerbic defence of the 'Covid Organics', 'many countries are trying out new treatments without clinical trials so why is Madagascar being singled out? Because we are offering a traditional remedy instead of a conventional drug?" (Baker, 2020, May 22). In the final analysis, whether the mode of these research projects around the world are in conformity with environmental best practises especially in the age of sustainable development, it is now impossible to say given the secrecy with which these scientific engagements were shrouded.

Following the United Nations, sustainable development is one that that 'meets the needs of the present generation without compromising the ability of future generations to meet their own needs'. It would appear that the approach of Africa's most visible candidate, Madagascar, in the global quest for a corona virus antidote, is quite in tandem with the thread and theory of sustainable development because of its total reliance on plant forms. To be sure, Africa's robust vegetative cover has long been noted for its role in global climate regulation and pharmaceutics. 


\section{ENVIRONMENTAL SUSTAINABILITY THROUGH DISEASE TREATMENT AND CONTROL: AN AFRICAN HERITAGE}

For a long time, the treatment of diseases and maladies through herbs and plants was viewed with some condescension in official circles in postcolonial Africa. However, this narrative is slowly undergoing some change as the real achievements of pre-colonial African societies in the sphere of medicine are now generally recognized' (Isichie, 1977, p.223). Elizabeth Isiche reports that a study in Ozuitem, in South-east Nigeria in 1938-9, of the finances of sixteen individuals showed that 'native medicine came high on the list and European medicine scarcely figured at all' (Isichie, 1977, p.198). This situation, amidst dysfunctional healthcare systems, still relatively holds true across the generality of African states. In fact, 'in subSaharan Africa today, traditional healers far outnumber modern health practitioners and the majority of the population uses traditional medicine. WHO estimates that $80 \%$ of people in low and middle-income countries rely primarily on traditional medicine for their primary health care needs' (King, 2002, p. 7).

At about time the turn of the twentieth century, evangelical Christians seeking converts in Igbo land, in a move that anticipated Western missions, used native traditional medicine to convert the people to Christianity. More specifically, 'to take our example this time from the Church Missionary Society, one of the best documented examples was Joseph Obinigbo Egbola who became a Christian in 1894'.

When he began his work at Akwukwu, everything was discouraging. The opposition of the heathen was great and the popular feeling ran high against the message he had to deliver. Very patiently he went about his work and gradually opposition began to give way... he was versed in the knowledge of herbal remedies and he put his knowledge into good practice for the benefit of the Akwukwu people. Many persons, once victims of repulsive ulcers, were cured by him and some of them are now grateful and humble followers of the Lord Jesus (Isichie, 1977, p. 164). 
Now it is important to note that traditional medical practice was not conducted in a random fashion in pre-colonial Africa. There was a guild, as there still are, to which the practitioners of traditional healing belonged. It was through this body that important discoveries in herbal medicine were diffused to the members far and wide. Thus, through very many centuries of tedious research, development and oral documentation African societies developed a reasonably reliable corpus of traditional medical healing.

In this connection we might well remember a certain Chive of Igbariam. Chive was a former dibia who had become a Christian and suggested to the local missionary in 1921 that a 'University of medicine' should be established where dibia could hand on their medical knowledge, in isolation from the corpus of traditional religious beliefs. The missionary scrubbed the proposal, telling Chive 'how organized society regarded quacks' (Isichie, 1977, p. 223).

It must be pointed out that early missionaries and colonial governments made strenuous but ultimately futile attempts to suppress traditional healing practices (King, 2002, 7). Thus it was in the observation of this obfuscationism by the colonial and much later the post-colonial state in Africa that Isichei could conclude that in Igboland and the rest of Africa 'the history of disease and its treatment and of epidemics is an important and neglected variable of social history' (Isichie, 1977, 223).

However, the advancement of the Covid Organics syrup by the Madagascan research institute on tropical plants appears as a timely regenerative serum not only for African tradition medicine and its practitioners but for the process of sustainable development which is intertwined with research based on the ecosystem.

\section{MADAGASCAR'S COVID ORGANICS; AN ECOLOGICAL INSPIRATION}

Madagascar shot to the fore of global scientific discourse when it advanced the Covid Organics syrup, derived from plant extracts obtained from its 
rich ecology, as a veritable cure for the lethal Covid-19 infection. However, asides from being initially mired in scientific controversy over procedural issues, the Covid Organics has now fallen into disrepute as a veritable antidote for the Covid-19 infection. Yet even amidst the seeming opprobrium of scientific disgrace; lessons abound for the world (in sustainable development) and for countries of the African continent (research and development and sustainable development). In this vein, amidst the Covid Organics controversy, the observation though in a different context of Peter Seebenger of the Max plank institute in Germany that 'even if the hopes for a drug based on the active ingredient against Covid-19 end in a disappointment it would be a gain' (Herrmann, 2020, July 15) is very apt.

Right from the outset, Madagascar had anchored its research and development program in pharmaceutics on the exploitation of its ecology through the conscious decision to 'promote traditional medicine' given the country's rich biodiversity and the central role of its traditional practitioners' (Razanamparany, 2020, May 1). Toward the attainment of this goal the Madagascan state established the Malagasy Institute of Applied Research (IMRA) and the National Pharmacology Research Centre. The former, established in 1957, played a prominent role in the formulation of the Covid Organics syrup. To be sure, the IMRA has an illustrious past with some 'fifty remedies to its credit, developed by combining traditional and modern medicine including the anti-diabetic drug madeglucyl and the cough suppressant madetoxin' (Razanamparany, 2020, May 1). The Centre is noted internationally for research in herbs and in fact it was founded through the 'financial benefits of a healing drug, madecassol which its founders Albert and Suzanne Rakoto Ratisimamanga derived from the Centella Asiatica plant' (Razanamparany, 2020, May 1). The institute also helped identify the Madagascan periwinkle's potential in cancer treatment; compounds isolated from the flower are now being used in treatments for breast, bladder and lung cancers (Baker, 2020, May 22). Presently around $10 \%$ of the Artemisinin requirement for malaria drugs is produced in Madagascar' (Herrmann, 2020, July 15). The Artemisia plant had been quite successful in 'inhibiting the first SAR Coronavirus (SARS-COV) which surfaced in Asia in 2002 (Herrmann, 2020, July 15,). Currently the IMRA is involved in research into phytochemistry, parasitic 
and cellular pharmacology, experimental diabetology, pharmacodynamics, toxicology and the analytical chemistry of essential oils.

Time magazine reported that, 'when news first emerged in January of a mysterious influenza-like disease in China that didn't respond to conventional treatment, IMRA's director general, Dr. Charles Andrianjara, got to work' (Baker, 2020, May 22). The outcome of that 'work' is Covid Organics. The outcome of the administration or dependence on Covid Organics' for the treatment of Covid-19 in Madagascar is a lockdown of the central region until July 26,2020 the threat of more lockdowns across the country and an appeal by the Madagascan health minister to aid agencies for medical essentials for aid workers ("coronavirus: Madagascar hospitals 'overwhelmed"'). Yet for all this the Madagascan scientific expedition is not a complete research 'failure'; scientifically it established some clarity. An error or failure does not in itself define the validation of a scientific research project. For example, Choloroquine Phosphate, an old drug for malarial, was once touted in learned scientific journals (and even by the president of the United States) as having 'demonstrated marked efficacy and acceptable safety in Covid-19' (Gao, Tian and Yang, 2020: 1). Today choloroquine phosphate has being dismissed as being risky as mortality rates among patients soared after its application (Freund, 2020, May 5). Even at that, the research effort expended on the Covid Organics was not totally in vain. The National Institute of Pharmaceutical Research and Development (NIPRD) in Nigeria in its analysis of the syrup concluded that it 'reduced cough frequency with the maximum dose tested' (Tih, 2020, July 20). Thus in the final analysis the ineffectiveness of the Covidorganics against Covid-19 pales in comparison to scientific clarity and other benefits it has brought about. Indeed, the invectives directed against the drug may have racial undertones as the Madagascan president, Andry Rajoelina, pointed out."I think the problem is that [the drink] comes from Africa and they can't admit...that a country like Madagascar...has come up with this formula to save the world" (Baker, 2020, May 22).

In another wise, the Madagascar example is probably the reason why several countries are now taking a fresh look at traditional healing as a way of combating the Covid-19. In Africa, particularly, it is now apparent that the scientific effort of the Madagascans with respect to herbal research has 
reignited the fervour of Africans to re-awake an age-long skill in herbal research. Presently, the World Health Organisation (WHO) and the Africa Centre for Disease Control (CDC) are collaborating closely on research into traditional remedies for Covid-19 (Forku, 2020, July 22). The Nigerian government on its part, in the wake of the Madagascan expedition, has jettisoned its former prosaic approach for a more proactive role in herbal research. In this respect it directed its drug regulatory agency, the National Agency for Food and Drug Administration and Control (NAFDAC) to assess plant based remedies as possible solution to the Covid-19 (Adebowale, 2020, July 28). The head of (NAFDAC) has also noted that there may be a possible link between the low death rate in Madagascar and the Covid Organics syrup (Moshood, 2020, May 9) Further showing an uncharacteristic openness toward herbal therapy the Nigerian government, together with several African states, took receipt of stocks of the Covid Organics syrup ("Coronavirus: what is Madagascar's 'herbal remedy' Covid-organics?" 2020, May 5). Similarly, one of the few states in Nigeria, Anambra, which has a Traditional Medicine Board to assess herbal drugs, is giving heightened credence to the activities of the board ("Anambra identifies six herbal drugs for covid-19 management", 2020, July 1). Furthermore, the Madagascan R\&D expedition has brought renewed focus on the Artemisia plant which is the active ingredient in the Covid Organics syrup. The Artemisia plant known locally as 'Tazargade' in Northern Nigeria has been used to fight off cold and flu, fever and body pains for ages in that region (Ekine, 2020, May 6).

To be sure, reliance on plant sources for medical remedies is environmentally friendlier than synthetic elements which make huge demands on energy. Furthermore, the logic of biodiversity dependency in research and development is enthralling - it is akin to a profitable circle - the need to engage in biodiversity based research ensures that the ecology must be protected thus giving rise to a clean environment and favourable income earning which reenergises the zeal to engage in biodiversity based research. It is this logic which has enabled Madagascar to remain in the forefront of herbal research worldwide. Consequently, without soiling its ecology, without poisoning its air, without shifting the natural mechanics of its climate, without altering its eco system, Madagascar is engaging in high 
level industrial export and acquiring international renown anchored on environmentally friendly research.

For a country like Nigeria the Madagascan exemplar is particularly relevant; despite the fact Nigeria is riddled with universities and research institutes not one has responded constructively to the global trauma inflicted by Covid-19. To be sure, even before the covid-19 pandemic research institutions and universities in Nigeria had, in the main, become cumbersome bureaucratic and labour exchanges concerned less with the tangible outcomes and more with the mundane benefits. The academic vacuity of Nigerian universities was made quite bare incidentally by the high profile corruption case involving government officials in the Niger Delta Development Commission (NDDC). The Niger Delta Development Commission (NDDC) had been set up by the federal government to facilitate infrastructural development in the long neglected Niger-Delta region of the country. During the public hearing of the matter at the National Assembly the acting managing director, a professor of microbiology, underwent a fainting spell under cross-examination. In addressing this issue Abimbola Adelakun (NDDC probe: to what end) makes a fundamental point about the innovative nullity of universities in Nigeria. The pungency and perceptiveness of her observation requires that we must quote her extensively.

I must admit that my feeling of a letdown from the whole nonsense did not kick in until I found out that Pondei was a professor. His profile says he studied medicine and surgery at the University of Lagos and was awarded a $\mathrm{PhD}$ in microbiology from the university of Birmingham, funny isn't it? The world is currently in the middle of a pandemic. Elsewhere in the world, scientists - including micro-biologists - have their heads bent in a laboratory somewhere as they research overcoming the disease. Here in the Third World, our trained professors of science are busy responding to corruption charges by fainting in the full glare of the public. How more aptly could the extent of our depravity be illustrated than what Pondei staged?

On the same day that a western university announced a breakthrough in the quest for Covid-19 vaccines, a professor of microbiology sits before a probe panel to respond to questions - no, not on anything that has to 
do with science - but on alleged financial misconduct. When we talk of brain drain people look in the direction of doctors feverishly writing professional exams to eventually escape Nigeria. However, is a case like Pondei not worse? Is that not why we sit by and wait while the rest of the world searches for a cure?

Lately the Academic Staff Union of Universities (ASUN) president, Biodun Ogunyemi, asked the federal government to keep schools closed till 2021. He was quite clear that his suggestion was about public safety, but it is still a sad commentary. We are not shutting schools in expectation of scientific solutions that we are working on currently; we are just bidding our time until the rest of the world that takes its knowledge seriously rescues us with vaccines. Not that we are bereft of human capacity, Nigeria has trained people from some of the world's best institutions. Some competent people just never get meaningfully engaged while others get seconded to bureaucracies where their brains are depleted on corruption probes ... ours is a country where religious organisations build universities but when a disease hits the land, they offer miracle healing. How would that not be when those that are supposed to do the hard work of studying for solutions are busy fainting before corruption probe panels?

The altitude of the African scientific community immersed in colonial mentality must also change. We have seen above how in colonial Nigeria an atavistic colonial official cavilingly dismissed a whole corpus of traditional medicine acquired over centuries. Such attitudes still persist among western trained scientists in Africa. For example in Tanzania, a medical doctor who collaborates with traditional healers in the treatment of People Living With Aids (PLWA) noted the 'resistance of her medical colleagues who asked her:"why do you collaborate with people who have never gone to school" '(King, 2002, p.20). This attitude must be changed in order to profitably assess the fullest benefit of the continent's abundant biodiversity. The Madagascan effort is a veritable prototype highlighting the possibilities inherent in research and development programme anchored on sustainable development. As IMRA's director general, Charles Andrianjara, argued 'We have a lot of wealth in our traditions and culture, and maybe we don't exploit it enough" (Barker, 2020, May 22). 
Finally, Madagascar by utilizing its biodiversity for development in an environmentally sustainable form it has guaranteed the preservation of the ecology for the use of future generations. In the Nigerian case, with flooding occasioned by human factors assailing vast tracts of the country, criminal pollution in the waterways especially in the Niger-delta, erosion and desert erosion caused by inane deforestation, the situation is grim. Indeed, if the unborn generation could survey their ecological bequest they would send the present and past generations of Nigerians their collective curses. Yet it is not too late to begin to make amends as professor Abert Rakoto Ratismamanga so aptly makes clear: 'We must move forward at our own pace we must above all have confidence in ourselves and in the therapeutic virtues of nature. For nature and man are one' (Razannamparany, 2020, May 1).

\section{CONCLUSION}

Thus with vaccine nationalism heading towards its crescendo, Madagascar's efforts have not only ensured that Africa receive honourable mention as a viable participant in the search for a cure for Covid-19, it has also superseded its western rivals by subsuming its research within the mechanics of sustainable development. However, the idea of research and development tied to sustainable development should extend beyond drug development alone to encompass every aspect of national life. The task for Africa presently is to ensure that its relative ecological purity is not unduly disturbed by an unnecessary mimicking of western technology and lifestyle. Similarly, research and development in agricultural technologies should centre more on the production of organic foods rather than tendency toward genetically modified foods. Exploration of alternative sources of energy should extend beyond electric and solar which are now common place but should encompass investigation into the vast natural resources of the continent for renewable energy to run its automobiles i.e. bio-fuels. Furthermore, research and development should accent the production of easily affordable bicycles which have the triple advantage of providing for easy mobility, low intensity exercise and a clean environment. Madagascar has shown the way. 


\section{BIBLIOGRAPHY:}

Adebowale, N. (2020, July 28). Nigerian govt directs NAFDAC to assess herbal mixture as possible COVID-19 treatment. Downloaded from: https://www.premiumtimesng. com/coronavirus/391945-nigerian-govt-directs-nafdac-to-assess-herbal-mixture-aspossible-covid-19-treatment.html\#.

Adelakun, A. (2020, July 23). NDDC probe, to what end?. Downloaded from: https:// punchng.com/nddc-probe-to-what-end/.

Anambra identifies six herbal drugs for COVID-19 management. (2020, May 5). Downloaded from: https://punchng.com/anambra-identifies-six-herbal-drugs-for-covid19-management/.

Baker, A. (2020, May 22). 'Could It Work as a Cure? Maybe.' A Herbal Remedy for Coronavirus Is a Hit in Africa, But Experts Have Their Doubts. Downloaded from: https:// time.com/section/health/.

Champion, M., (2020, May 8). Trump's Going All In on a Vaccine. He May Still Get Beaten by China. Downloaded from: https://www.bloomberg.com/news/features/ 2020-05-08/ coronavirus -vaccine-race-between-u-s-china-has-high-stakes?htmlsource=url_link.

Chinese consulate in Houston ordered to close by US. (2020, July 23). Downloaded from: https://www.bbc.com/news/world-us-canada-53497193\#core-navigation/.

Coronavirus: Madagascar hospitals 'overwhelmed'. Downloaded from: https://www.bbc. com/news/world/africa.

Coronavirus: What is Madagascar's , herbal remedy' Covid-Organics? (2020, May 5). Downloaded from: https://www.aljazeera.com/amp/news/2020/05/coronavirusmadagascar-herbal-remedy-covid-organics-200505131055598.html.

Deng, C., (2020, June 5). In Race for Covid-19 Vaccine, China Tries for a Coup. The Wall Street Journal. Downloaded from: https://www.wsj.com/articles/in-race-for-covid19-vaccine-china-tries-for-a-coup-11591354803.

Editorial, (2020). Covid-19: Fighting panic with information. The Lancet. No. 395, p. 537. Downloaded from: https://www.thelancet.com.

Ekine, M. (2020, May 6). Madagascar coronavirus cure - Wetin you need to know about di drink. Downloaded from: https://www.bbc.com/pidgin.

Forku, R. (2020, July 22). WHO, Africa CDC form covid-19 traditional remedy panel. AA. Downloaded from: https://www.aa.com.tr/en/latest-on-coronavirus-outbreak/

Fox, C., and Kelion, L. (2020, July 16). Coronavirus: Russian spies target covid-19 vaccine research. Downloaded from: https://www.bbc.com/news/technology-53429506\#corenavigation. 
Freund, A., (2020, May 5). Hydroxycholoquine: using anti-malarial drug is a risky business. Downloaded from: https://m.dw.com/en/top-stories/s-9097.

Heinberg, R. (2006). The Oil Depletion Protocol: a plan to avert oil wars, terrorism and economic collapse. Clairview.

Herrmann, C. (2020, July 15). Tests for 'miracle cure' herb Artemisia. Downloaded from: https://w.dw.com/en/top-stories/5-9097.

Isichei, E. (1977). A History of the Igbo People ( $2^{\text {nd }}$ ed.). The Macmillan Press ltd. Joshi, M. (2020, June 9).the race for covid-19 vaccine. The Tribune. Downloaded from: https://m.tribuneindia.com/news/comment/the-race-for-covid-19-vaccine-96464.

King, R. (2002). Ancient Remedies, New Disease; involving traditional healers in increasing access to Aids care and prevention in East Africa. UNAIDS. https://www.unaids. org.

Kobayashi, T., Jung, S., Linton, N.M., Kinoshita, R., Hayashi, K., Miyama, T., Anzai, A., Yang, Y., Yuan, B., Akhmetzhanov, A. R., Suzuki, A. and Nishiura, H. (2020). Communicating the risk of death from novel coronavirus disease (COVID-19). Journal of Clinical Science. No. 9, pp. 1-7. Downloaded from: https://doi:10.3390/jcm9020580.

Lau, H., Khosrawipour, V., Kocbach, P., Mikolajczyk, A., Schubert, J., Bania, J., and Khosrawipour, T. (2020). The positive impact of lockdown in Wuhan on containing the COVID-19 outbreak in China. Downloaded from: https://academic.oup.com/jtm/ advance-article-abstract/doi/10.1093/jtm/taaa037/5808003.

Moshood, Y. (2020, May 9). Madagascar's covid organics likely a preventive remedyNAFDAC. Downloaded from: https://healthwise.punchng.com/Madagascar's- covid -organics- likely-a-preventive-remedy-nafdac.

Myre, G., (2020, May 27). In the battle against covid-19, a risk of 'vaccine nationalism' Downloaded from: https://www.npr.org/programs/morning-edition/2020/05/27/ 862887707/morning-edition-for-may-27-2020.

Razanamparany, M. (2020, May 1). Coronavirus: Madagascar's 'covid-organics' born from local tradition Downloaded from: https://www.theafricareport.com.

Ren, D. (2020, June 15). Who is in the global competition to develop a coronavirus vaccine? South China Morning Post. Downloaded from: https://www.scmp.com/topics/ coronavirus-pandemic.

Rowland, C., Johnson, C.Y. and Wan, W. (2020, May 11). Even finding a covid-19 vaccine won't be enough to end the pandemic. The Washington Post. Downloaded from: https://www.washingtonpost.com/business/.

Sanger, E.D., Kirkpatrick, D.D., Wee, S., and Bennhold, K. (2020, March 19). Search for coronavirus vaccine becomes a global competition. The New York Times. Downloaded from: https://www.nytimes.com/2020/07/27/world/coronavirus-covid-19.html.

Sohrabi, C., Alsafi Z., O’Neill N., Khan M., Kerwan A., Al-Jabir A., Iosifidis C, and Agha R. (2020). World Health Organization declares global emergency: A review of the 
2019 novel Coronavirus (COVID-19), International Journal of Surgery, pp. 1-10. Downloaded from: https://doi.org/10.1016/j.ijsu.2020.02.034.

Sun, P., Lu, X., Xu, C., Sun, W., and Pan, B. (2020). Understanding of COVID-19 based on current evidence, pp. 1-16. Downloaded from: https://doi:10.1002/jmv.25722.

Tih, F. (2020, July 20). Nigeria: Madagascar's herb drink cannot curecovid-19. Downloaded from: https://www.com.tr/en/latest-on-coronavirus-outbreak.

Trilla, A. (2020). Un mundo, una salud: la epidemia por el nuevo coronavirus COVID-19 (trans. One world, one health: The novel coronavirus Covid- 19 epidemic). Med Clin (Barc), pp. 1-3. Downloaded from: https://doi.org/10.1016/j.medcli.2020.02.002.

US charges Chinese covid-19 research 'cyber spies'. (2020, July 21). Downloaded from: https://www.bbc.com/news/world-us-canada-53493028\#core-navigation.

Wang, C., Cheng, Z., Yue, X., and McAleer, M. (2020). Risk management of COVID-19 by universities in China. Journal of Risk and Financial Management, No. 13/36, pp. 1-6. Downloaded from: https://doi:10.3390/jrfm13020036.

Wu, Z., and McGoogan, J.M. (2020). Characteristics of and important lessons from the coronavirus disease 2019 (COVID-19) outbreak in China: Summary of a report of 72314 cases from the Chinese Centre for Disease Control and Prevention. American Medical Association, E1-E4. Downloaded from: https://jamanetwork.com/journals/ jama/fullarticle/10.1001/jama.2020.2342?utm_campaign=articlePDF\%26utm_ medium $=$ articlePDFlink\%26utm_source=articlePDF\%26utm_content=jama.2020.2648. 